\title{
Small-Cell Lung Cancer Metastases in Breast
}

\author{
Küçük Hücreli Akciğer Kanserinin Meme Metastazı
}

Nilgün Yılmaz Demirci, Y' Yurdanur Erdoğan, ${ }^{2}$ Funda Demirağ, ${ }^{2}$ Aydın Yılmaz, ${ }^{1}$ Ülkü Yılmaz, Çiğdem Biber'

\begin{abstract}
Although primary breast tumors are quite common, metastatic involvement of all breast masses are rare and account for about $1-5 \%$ of cases. A 56 -year-old female patient was admitted to our clinic in July 2009 with complaints of shortness of breath. Thoracic computed tomography (CT) scan showed a mass in the left hilar region. Endobronchial lesion was determined by fiberoptic bronchoscopy and the biopsy was evaluated as small cell lung carcinoma. The patient was followed-up after 4 cycles of etoposide + cisplatin chemotherapy. In the follow-up period, due to an increase in shortness of breath the patient was admitted to our clinic again in April 2010. A $4 \times 3 \times 3 \mathrm{~cm}$ sized mass in the right upper quadrant of breast lesions obtained for re-staging positron emission tomography (PET-CT) showed intense FDG uptake increase. Needle biopsy of the breast was evaluated as a result of metastasis of small cell lung carcinoma. The patient recieved second-line VAC chemotherapy in April 2010. This case of small-cell lung cancer and breast metastases is presented because of its rarity.

Key words: Breast, metastasis, small cell lung carcinoma.
\end{abstract}

\section{Özet}

Primer meme tümörleri yaygın olmasına rağmen memenin metastatik tutulumu nadirdir ve yaklaşık \%1-5 oranında görülür. Elli altı yaşında kadın hasta Temmuz 2009'da nefes darlığı yakınması ile kliniğimize başvurdu. Toraks bilgisayarlı tomografisinde (BT) sol hiler kitle mevcuttu. Fiberoptik bronkoskopi ile saptanan endobronşiyal lezyondan alınan biyopsi sonucu küçük hücreli akciğer karsinomu (KHAK) olarak geldi. Hastaya 4 kür etoposid sisplatin kemoterapisi verildi ve sonrasında takibe alındı. Nisan 2010'da nefes darlığında artış yakınması ile tekrar kliniğimize kabul edildi. Yeniden evreleme amaçlı çekilen PET-BT'de sağ meme dış kadranda $4 \times 3 \times 3 \mathrm{~cm}$ ebadında SUVmax 13,29 olan artmış FGD tutulumu raporlandı. Memedeki lezyondan alınan biyopsi sonucu KHAK metastazı şeklinde değerlendirildi. Hastaya 2. basamak VAC (vincristin, adriyamisin, siklofosfamid) kemoterapisi başlandı. KHAK'nin memeye metastazı nadir olması nedeni ile sunuldu.

Anahtar Sözcükler: Meme, metastaz, küçük hücreli akciğer kanseri.

\footnotetext{
'Clinic of Chest Diseases, Atatürk Chest Disease and Chest Surgery Training and Research Hospital, Ankara, Turkey

${ }^{2}$ Department of Pathology, Atatürk Chest Disease and Chest
} Surgery Training and Research Hospital, Ankara, Turkey

'Atatürk Göğüs Hastalıkları ve Göğüs Cerrahisi Eğitim Araştırma Hastanesi, Göğüs Hastalıkları Kliniği, Ankara

${ }^{2}$ Atatürk Göğüs Hastalıkları ve Göğüs Cerrahisi Eğitim Araştırma Hastanesi, Patoloji Bölümü, Ankara

Submitted (Başvuru tarihi): 18.05.2013 Accepted (Kabul tarihi): 10.07.2013

Correspondence (iletişim): Nilgün Yılmaz Demirci, Clinic of Chest Diseases, Atatürk Chest Disease and

Chest Surgery Training and Research Hospital, Ankara, Turkey

e-mail: nilgundemirci@gmail.com 
Breast cancer is the leading cause of death from cancer in women. The metastatic involvement of the breast from non-mammary neoplasms is a relatively rare condition (1) We report a case of small cell lung cancer associated with a metastatic lesion to the breast with a review of the literature about this rare entity.

\section{CASE}

A 56-year-old female patient was admitted to our clinic in July 2009 with a complaint of shortness of breath. The case was a housewife and had a smoking history of 40 packs/year. In her respiratory system examination, breath sounds on the left mid-lower zone were diminished. The chest $X$-ray revealed an increased opacity in the left middle-lower zone (Figure 1). Thoracic computed tomography (CT) scan showed a mass in the left hilar region. Whole-body 18F-fluorodeoxyglucose positron emission/computed tomography (18F-FDG PET/CT) scan demonstrated an intense 18F-FDG uptake in left hilar area. The maximum standardized uptake value (SUVmax) measurements of the lesion were 12.69. Additionally, a 1 $\mathrm{cm}$ nodule in the right upper quadrant of her right breast demonstrated an intense 18F-FDG uptake with SUVmax 1.94. The lesion was examined by mammography and breast ultrasonography and evaluated as fibroadenoma. Also, in the cranium at the vertex level, a mass lesion approximately $5.77 \times 6.7 \mathrm{~cm}$ that led to destruction in the frontal region bone was observed. This lesion had increased metabolic activity (SUVmax: 7.81). Endobronchial lesion was determined by fiberoptic bronchoscopy and the biopsy was evaluated as small cell lung carcinoma. Fine needle aspiration biopsy of the cranial lesion was performed and malignancy was suspected. The patient was evaluated with extensive stage small-cell lung cancer was started on four cycles of chemotherapy (etoposide $100 \mathrm{mg} / \mathrm{m}^{2}$ and cisplatin $80 \mathrm{mg} / \mathrm{m}^{2}$ ). In the follow-up period, due to increased shortness of breath, the patient was admitted to our clinic again in April 2010 During systemic investigation, two well-enhanced nodules were found in the right upper quadrant of her right breast For re-staging, PET-CT was obtained. The 18F-FDG uptake in left hilar area was stable. The cranium showed no $18 \mathrm{~F}-F D G$ uptake. A $4 \times 3 \times 3 \mathrm{~cm}$ sized mass in the right upper quadrant of breast lesions showed intense FDG uptake. The needle biopsy of the breast was evaluated as a result of metastasis of small cell lung carcinoma (Figure 2 and 3). Second-line chemotherapy of vincristine, adriamycin and cyclophosfamide (VAC) was initiated. Her clinical condition progressively deteriorated due to un- controlled disease and she died after two cycles of VAC. The median survival was 11 months.

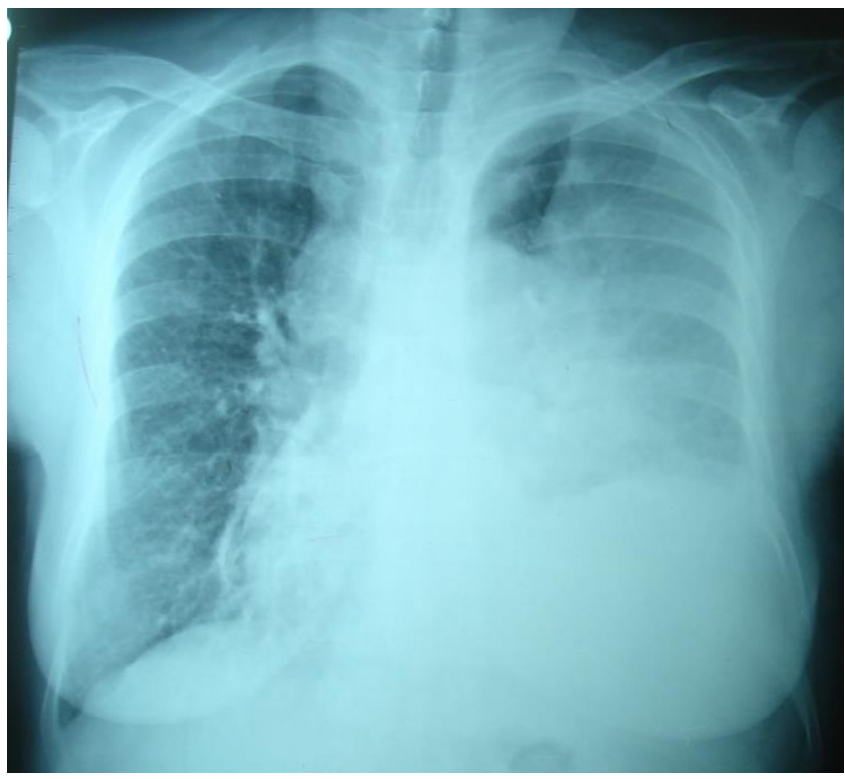

Figure 1: The chest roentgenogram; an increased opacity in the left middle-lower zone.

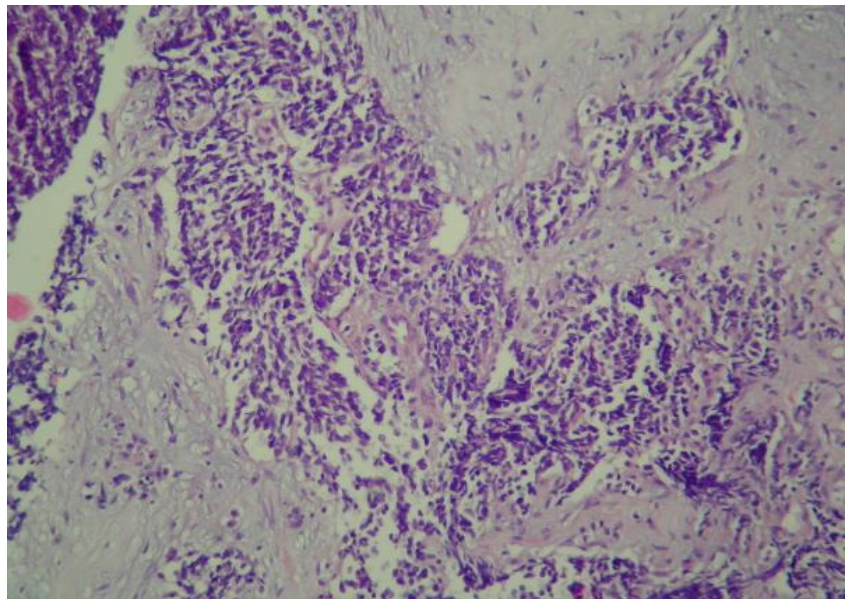

Figure 2: Tumoral cells infiltrating breast tissue (HEX400).

\section{DISCUSSION}

Primary breast carcinoma is the most common neoplasm in women. Although primary breast carcinoma is the most common tumor in women in the world, metastases to the breast from solid tumors are quite rare (2). Although metastases to the breast constitute up to $6 \%$ in autopsy series, clinically observed incidence varies from 0.5 to $1.2 \%$ of all breast neoplasms $(3,4)$. In a retrospective survey of 14,000 breast malignancies, secondary involvement of breast was found to be $3.2 \%$, but most were metastatic from the contralateral breast carcinomas, and only $0.43 \%$ was found to be non-mammary metastases (5). Alva et al. reviewed the data from 1855 to 1998, 
and found a total of 431 cases of extramammarian solid breast metastasis (2).

Hematopoietic neoplasms, especially lymphomas, involve the breasts secondarily more often than solid tumors. Among nonhematopoietic neoplasms, malignant melanoma, and bronchogenic tumors are the most common secondary breast tumors of non-mammary solid tumors $(2,3,4,6,7,8)$

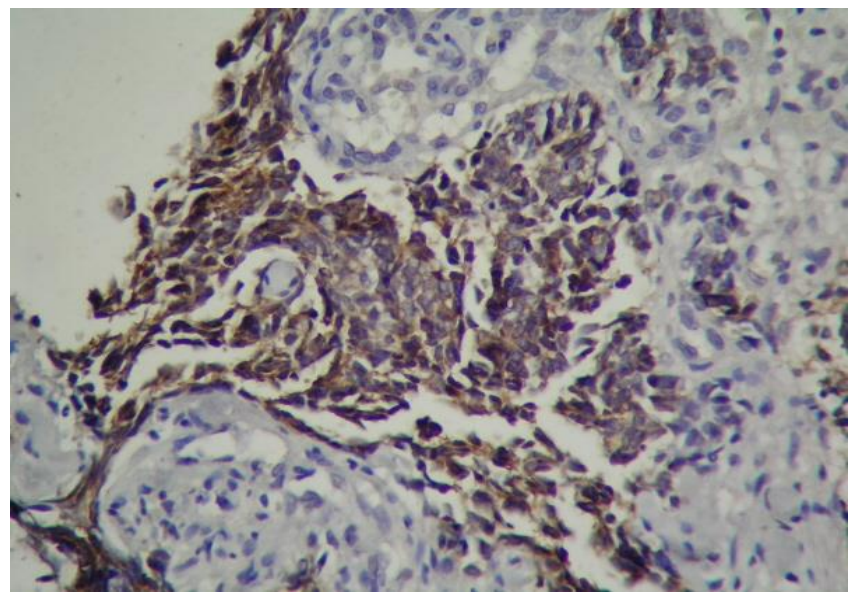

Figure 3: CD56 positivity in tumoral cells (CD56X400).

Metastasis to the breast may occur by two distinct routes: lymphangitic and hematogeneous. Melanoma is the most common source of hematogeneous metastasis to the breast followed in decreasing frequency by lung cancer, soft tissue sarcomas, and ovarian cancer. Lymphangitic metastases most commonly occur from primary carcinoma of the opposite breast (9). Tumor cells of lung cancer may reach the breast either from thoracic cavity lymphatic spread or through thoracic duct to systemic circulation and then reached the contralateral breast (10). Ipsilateral metastases have been previously reported (11). In the current case, metastasis was in the contralateral breast.

The majority of breast metastasis present as palpable, well circumscribed, painless breast masses with predilection to the upper outer quadrant $(12,13)$. The present case had metastatic lesion in the right upper quadrant of her right breast.

Small cell lung cancer (SCLC) accounts for $16 \%$ of all lung cancers (14). Nearly all cases of SCLC are attributable to cigarette smoking. When compared to non-small cell lung cancer, SCLC generally has a more rapid doubling time, a higher growth fraction and earlier development of widespread metastases (15). Most patients with SCLC present with hematogenous metastases, while only about one third of patients present with limited disease confined to the chest (16). Approximately two thirds of patients present with overt hematogenous metastases, which commonly involve the contralateral lung, liver, adrenal glands, brain, bones, and bone marrow (15). In patients with limited-stage disease, response rates of $70 \%$ to $90 \%$ are expected after treatment with cisplatin and etoposide plus thoracic radiotherapy, while in the extensive-stage disease, response rates of $60 \%$ to $70 \%$ can be achieved with combination chemotherapy alone (16). Unfortunately, median survival rates are only 14 to 20 months and 9 to 11 months for patients with limited-stage and extensive-stage disease, respectively (17).

Positron emission tomography with computed tomography (PET-CT) is a noninvasive imaging modality that has been reported to be useful in whole body staging, restaging, and monitoring of treatment response in breast cancer patients (18). Results demonstrating the superiority of PET CT over anatomic imaging modalities in the detection of distant metastases are relatively well documented. Fuster et al. (19) found the overall sensitivity and specificity of PET CT in detecting distant metastases to be $100 \%$ and $98 \%$, respectively, versus $60 \%$ and $83 \%$, respectively, for conventional imaging.

Although, secondary breast involvement from solid tumors is rare, a breast mass can be the first manifestation of relapse or part of a disseminated disease, and usually predicts poor survival $(3,4,20,21)$. The mass in left hilar area was stable and progression was only in the breast. The current case died 2 months after detection of breast metastasis and overall survival was 11 months.

In conclusion, the metastatic involvement of the breast from non-mammary neoplasms is a relatively rare condition. Metastasis of SCLC to breast is very rare, also. This case and review of literature support that the prevalence of breast metastasis in patients with small cell lung cancer is very low.

\section{CONFLICTS OF INTEREST}

None declared.

\section{AUTHOR CONTRIBUTIONS}

Concept - N.Y.D., Y.E., F.D., A.Y., Ü.Y., Ç.B.; Planning and Design - N.Y.D., Y.E., F.D., A.Y., Ü.Y., Ç.B.; Supervision - N.Y.D., Y.E., F.D., A.Y., Ü.Y., Ç.B.; Funding N.Y.D., Y.E., F.D., A.Y., Ü.Y., Ç.B.; Materials - N.Y.D., Ü.Y.; Data Collection and/or Processing - N.Y.D., A.Y.; Analysis and/or Interpretation - N.Y.D., Ü.Y.; Literature Review - Ç.B., Y.E.; Writing - N.Y.D.; Critical Review N.Y.D., Y.E., F.D. 


\section{YAZAR KATKILARI}

Fikir - N.Y.D., Y.E., F.D., A.Y., Ü.Y., Ç.B.; Tasarım ve Dizayn - N.Y.D., Y.E., F.D., A.Y., Ü.Y., Ç.B.; Denetleme N.Y.D., Y.E., F.D., A.Y., Ü.Y., Ç.B.; Kaynaklar - N.Y.D., Y.E., F.D., A.Y., Ü.Y., Ç.B.; Malzemeler - N.Y.D., Ü.Y.; Veri Toplama ve/veya İşleme - N.Y.D., A.Y.; Analiz ve/veya Yorum - N.Y.D., Ü.Y.; Literatür Taraması - Ç.B., Y.E.; Yazıyı Yazan - N.Y.D.; Eleştirel Inceleme - N.Y.D., Y.E., F.D.

\section{REFERENCES}

1. Oksüzoğlu B, Abali H, Güler N, Baltali E, Ozişik Y. Metastasis to the breast from nonmammarian solid neoplasms: a report of five cases. Med Oncol 2003; 20:295-300.

2. Alva S, Shetty-Alva N. An update of tumor metastasis to the breast data. Arch Surg 1999; 134:450. [CrossRef]

3. Hajdu SI, Urban JA. Cancer metastatic to the breast. Cancer 1972; 29:1691-6. [CrossRef]

4. Bohman LG, Bassett LW, Gold RH, Voet R. Breast metastases from extramammary malignancies. Radiology 1982; 144:309-12.

5. Georgiannos SN, Chin J, Goode AW, Sheaff M. Secondary tumors of the breast: a survey of 20th century. Cancer 2001; 92:2259-66.

6. Cangiarella J, Symmans WF, Cohen JM, Goldenberg A, Shapiro RL, Waisman J. Malignant melanoma metastatic to the breast: a report of seven cases diagnosed by fineneedle aspiration cytology. Cancer 1988; 84:160-2. [CrossRef]

7. Sneige N, Zachariah S, Fanning S, Dekmezian RH, Ordonez NG. Fine-needle aspiration cytology of metastatic neoplasms in the breast. Am J Clin Pathol 1989; 92:2735.

8. Inoue $T$, Tanaka E, Sakuramoto M, Minakuchi M, Maeda $Y$, Maniwa K, et al. A case of small cell lung cancer with an initial symptom of breast metastasis. Nihon Kokyuki Gakkai Zasshi 2006; 44:39-42.

9. Chung SY, Oh KK. Imaging findings of metastatic disease to the breast. Yonsei Med J 2001; 42:497-502.

10. Ji FF, Gao P, Wang JG, Zhao J, Zhao P. Contralateral breast metastasis from pulmonary adenocarcinoma: two cases report and literature review. J Thorac Dis 2012; 4:384-9. [CrossRef]
11. Huang HC, Hang JF, Wu MH, Chou TY, Chiu CH. Lung adenocarcinoma with ipsilateral breast metastasis: a simple coincidence? J Thorac Oncol 2013; 8:974-9. [CrossRef]

12. Lee $\mathrm{AH}$. The histological diagnosis of metastases to the breast from extramammary malignancies. J Clin Pathol 2007; 60:1333-41. [CrossRef]

13. Williams SA, Ehlers RA 2nd, Hunt KK, Yi M, Kuerer HM, Singletary $S E$, et al. Metastases to the breast from nonbreast solid neoplasms: presentation and determinants of survival. Cancer 2007; 1 10:731-7. [CrossRef]

14. Jemal A, Siegel R, Ward E, Hao Y, Xu J, Thun MJ. Cancer statistics, 2009. CA Cancer J Clin 2009; 59:225-49. [CrossRef]

15. Simon G, Ginsberg RJ, Ruckdeschel JC. Small-cell lung cancer. Chest Surg Clin N Am 2001; 11:165-88.

16. Simon M, Argiris A, Murren JR. Progress in the therapy of small cell lung cancer. Crit Rev Oncol Hematol 2004; 49:1 19-33. [CrossRef]

17. Chute JP, Chen T, Feigal E, Simon R, Johnson BE. Twenty years of phase III trials for patients with extensive-stage small-cell lung cancer: perceptible progress. J Clin Oncol 1999; 17:1794-801.

18. Keam B, Im S-A, Koh Y, Han SW, Oh DY, Cho N, et al. Predictive value of FDG PET/CT for pathologic axillary node involvement after neoadjuvant chemotherapy. Breast Cancer 2013; 20:167-73. [CrossRef]

19. Fuster D, Duch J, Paredes P, Velasco M, Munoz M, Santamaria $G$, et al. Preoperative staging of large primary breast cancer with [18F]fluorodeoxyglucose positron emission tomography/computed tomography compared with conventional imaging procedures. J Clin Oncol 2008; 26:4746-51. [CrossRef]

20. Amichetti M, Perani B, Boi S. Metastases to the breast from extramammary malignancies. Oncology 1990; 47:257-60. [CrossRef]

21. Toombs BD, Kalisher L. Metastatic disease to the breast: clinical, pathologic, and radiographic features. AJR Am J Roentgenol 1977; 129:673-6. [CrossRef] 